Research Article

\title{
Effect of Polypropylene Fiber on the Flexural Strength Properties of Lightweight Foam Mixed Soil
}

\author{
Raksiri Sukkarak, ${ }^{1}$ Pornkasem Jongpradist $\mathbb{D}^{1},{ }^{1}$ Pitthaya Jamsawang $\mathbb{D}{ }^{2}$ \\ Piti Sukontasukkul, ${ }^{3}$ and Prinya Chindaprasirt $\mathbb{D}^{4}$
}

${ }^{1}$ Civil Engineering Department, Faculty of Engineering, King Mongkut's University of Technology Thonburi, Thung Khru, Bangkok, Thailand

${ }^{2}$ Soil Engineering Research Center, Department of Civil Engineering, King Mongkut's University of Technology North Bangkok, Bangkok, Thailand

${ }^{3}$ Construction and Building Materials Research Center, Department of Civil Engineering, King Mongkut's University of Technology North Bangkok, Bangkok, Thailand

${ }^{4}$ Sustainable Infrastructure Research and Development Center, Department of Civil Engineering, Khon Kaen University, Khon Kaen, Thailand

Correspondence should be addressed to Pitthaya Jamsawang; pitthaya.j@eng.kmutnb.ac.th

Received 22 December 2018; Accepted 31 March 2019; Published 18 April 2019

Academic Editor: Antonio Caggiano

Copyright (c) 2019 Raksiri Sukkarak et al. This is an open access article distributed under the Creative Commons Attribution License, which permits unrestricted use, distribution, and reproduction in any medium, provided the original work is properly cited.

\begin{abstract}
This study examines the effect of polypropylene fiber on the flexural strength properties of lightweight foam mixed soil (LFS). The flexural properties of LFS comprising different proportions of polypropylene fiber $(58 \mathrm{~mm})$ at different volume fractions $(0.5 \%$, $0.75 \%$, and $1 \%$ ), three different cement contents of 100,150 , and $200 \mathrm{~kg} / \mathrm{m}^{3}$, and densities of $0.8,1.0$, and $1.2 \mathrm{~g} / \mathrm{cm}^{3}$ were thoroughly investigated. The flexural performance of LFS according to ASTM C1609 was achieved after 28 days of aging. The results show that the flexural characteristics of LFS could be enhanced by fiber additives, as indicated by the increase in the flexural/residual strength and equivalent flexural strength ratio. The flexural performance is also related to the mixing components, including the density and cement content. For the toughness behavior, the equivalent flexural strength ratio reached up to $100 \%$, which could be achieved with the strain-hardening specimens. The fiber inclusion is more efficient with an increase in the density and cement content of specimens as shown by the overall rating of the flexural performance.
\end{abstract}

\section{Introduction}

An improvement in the properties of soil is necessary due to constraints imposed by constructions in problematic areas such as areas with low-strength and high-compressibility soil. Two main categories of soil improvement include improvement of the in situ foundation soil and improvement of the filled soil. Lightweight cement-treated soil is well recognized among geotechnical engineers and has been used in many civil engineering applications, such as embankment material on soft ground, backfill material, filling material, and filter material [1-3]. This improvement technique was first used in Norway for road embankment structures in
1972 [4], and later, the volume of such constructions increased rapidly. Among the various types of lightweight cement-treated soil, lightweight foam mixed soil (LFS) is one of the most popular materials in road embankment construction. The main strategy is to add cement content and foam in an amount that increases the strength and decreases the density of the mixture, respectively. The mechanical properties of LFS under various loading conditions and mixing components have been studied [2, 5-9]. The influence of cement content, curing time, density, and proportion of foaming agent on the strength behavior of lightweight foam mixed soils has been studied by laboratory tests. With good performance, low price, and well-controlled 
production, the utilization of LFS has been extended to various applications, particularly the maintenance of road structure and approach to bridges under operation. For main roads where operations cannot be suspended for a long time, precast LFS is preferred. The LFS can be produced in a plant nearby or even at the construction site; and the precast LFS from nearby plants is transported to the construction location. However, with high cement content and low densities, the structure of LFS consists of a cement-soil matrix and a large amount of both pores and voids (larger). As a result, the LFS exhibits extremely brittle behavior $[6,7]$. This brittle behavior is becoming an important consideration, particularly in the use of precast LFS. During transportation and installation, cracking and chipping can easily occur. This imparts unfavorable properties to the repaired road.

Extensive literature has reported that the addition of various types of randomly discrete fibers into a cementitious matrix is well recognized and widely practiced for various structural applications. Fiber inclusion leads to improvements in the mechanical behavior of cement-treated soils under shear [10-19], compression [20-23], and flexural [24-26] test conditions. Yetimoglu and Salbas [27] stated that the shear strength and stress-strain behaviors of sands reinforced with a random distribution of discontinuous fibers depend on the fiber content, aspect ratio, and surface friction between the fiber and cemented matrix. Temel et al. [28] concluded that the fiber content has a strong effect on the bearing capacity, stiffness, and ductility of sand fills reinforced with fiber inclusion. Estabragh et al. [29] demonstrated that the mechanical behavior of soil-cement-fiber mixtures is a function of the fiber content and curing time. According to the results of an experimental study by Casagrande et al. [30], an increase in the fiber length and content results in an increase in the peak strength of fiberreinforced bentonite materials. Fiber inclusion has been proven to be efficient in cement-soil structures. However, for materials with cement-soil structures with large voids, such as the LFS, little investigation has been conducted to reveal the effects of fiber inclusion on their mechanical behavior.

The objective of this study was to investigate the flexural characteristics of LFS that are improved by polypropylene fiber. To achieve this aim, the entire testing program for the laboratory tests includes simple physical property tests and flexural performance tests. The polypropylene fiber is prepared at three different volume fractions: $0.5 \%, 0.75 \%$, and $1 \%$. The desired unit weights of LFS are $0.8,1.0$, and $1.2(\mathrm{~g} /$ $\mathrm{cm}^{3}$ ) prepared by varying the quantity of foam. Three different cement contents $\left(100,150\right.$, and $\left.200 \mathrm{~kg} / \mathrm{m}^{3}\right)$ of soil are used. The curing period of specimens is fixed at 28 days. Finally, the overall rating of flexural performance is applied to provide useful insight for evaluating the efficiency of the fiber content on the flexural behavior of the LFS material.

\section{Materials}

In this study, soft clay classified as $\mathrm{CH}$ in the Unified Soil Classification System (USCS) from the campus of King Mongkut's University of Technology Thonburi, Thailand, was used in all tests. The fiber material used in the present study was polypropylene fiber, which is widely employed in fiber-reinforced cemented soil [24, 25, 31-38]. The polypropylene fiber was prepared with a length of $58 \mathrm{~mm}$ at three different volume fractions: $0.5 \%, 0.75 \%$, and $1 \%$. Type I Portland cement was used in this study. The foam was made by mixing foaming material and air in an air foam generator. The required density was $0.05 \mathrm{t} / \mathrm{m}^{3}$. The foaming material was made by diluting the foaming agent with water, and the proportion of the mixture (foaming agent: water) is $1: 19$, as suggested by PWRI [39]. The basic physical properties of the materials used in this study are shown in Table 1.

\section{Testing Procedure and Program}

\subsection{Sample Preparation}

3.1.1. Method of Remolding the Clay. The clay used herein was remolded until it became mud. The water contents were set as the liquid limit (LL) of approximately 1.5-3.0 LL. The purpose of the remolding water content is to increase the workability and flowability. To prevent the bleeding of aircement-treated soil, a flow value of $450 \mathrm{~mm}$ from the flow test is required [39]. Prior to the addition of cement content and foam, natural soil was mixed with the associated addition of water. The remolding clay water content $\left(w^{*}\right)$ is hereinafter defined as the water content of the remolded clay prior to the addition of cement content and foam. The amount of water added to a wet clay sample to obtain the desired remolding water content was calculated by the following fundamental equation:

$$
\Delta W_{\mathrm{W}}=\frac{W_{\mathrm{T}}}{1+w_{0}}\left(w^{*}-w_{0}\right),
$$

where $\Delta W_{\mathrm{W}}, W_{\mathrm{T}}, w^{*}$, and $w_{0}$ are the additional weight of water to be added, total weight of prepared original untreated clay sample, required remolding clay water content, and natural water content of the clay sample, respectively. The samples of base clay with the required amount of additional water were placed inside a portable mechanical soil mixer and allowed to mix thoroughly for a few hours. When the mixed clay was uniformly remolded, the water content was closer to the desired remolding water content within $\pm 1 \%$, and the sample was then ready for admixture mixing. The clay sample or mud was placed in a humid room overnight to maintain the water content of the sample.

3.1.2. Mixing Procedures. The preparation of the specimens is shown in Figure 1. The specimen was $100 \mathrm{~mm}$ wide, $100 \mathrm{~mm}$ high, and $350 \mathrm{~mm}$ long. Prior to admixing with foam, the prepared remolded clay sample at a particular remolding water content was mixed with cement and polypropylene fiber inside the soil mixer for approximately 6 minutes until the mixture became a slurry. A constant remolding water content of $300 \%$ was used in all tests. Subsequently, air foam was added and mixed with the slurry. The desired density of air-cement-treated soil was adjusted to achieve the target density within a range of $\pm 0.03 \mathrm{~g} / \mathrm{cm}^{3}$, 
TABLe 1: Properties of materials.

\begin{tabular}{|c|c|}
\hline Material & Properties \\
\hline Bangkok clay & $\begin{aligned} \mathrm{LL}=117 \%, \mathrm{PL}=39 \%, \mathrm{PI} & =78 \%, \text { water content }=84 \%, \\
G_{s} & =2.65\end{aligned}$ \\
\hline Polypropylene fiber & $\begin{array}{c}\text { Length }=58 \mathrm{~mm} \text {, section }=\text { Rect. } 1.0 \times 0.5 \text {, fiber aspect ratio } \\
(\text { length } / \text { diameter })=52, \text { tensile strength }=450 \mathrm{~N} / \mathrm{mm}^{2}, \\
G_{\mathrm{s}}=0.91, \text { shape }=\text { fully crimped }\end{array}$ \\
\hline \multicolumn{2}{|c|}{ Portland cement type I } \\
\hline Fly ash & ASTM C 618 (class F) \\
\hline Foam & Density $=0.05 \mathrm{t} / \mathrm{m}^{3}$ \\
\hline
\end{tabular}

LL: liquid limit; PL: plastic limit; PI: plasticity index; $G_{s}$ : specific gravity.

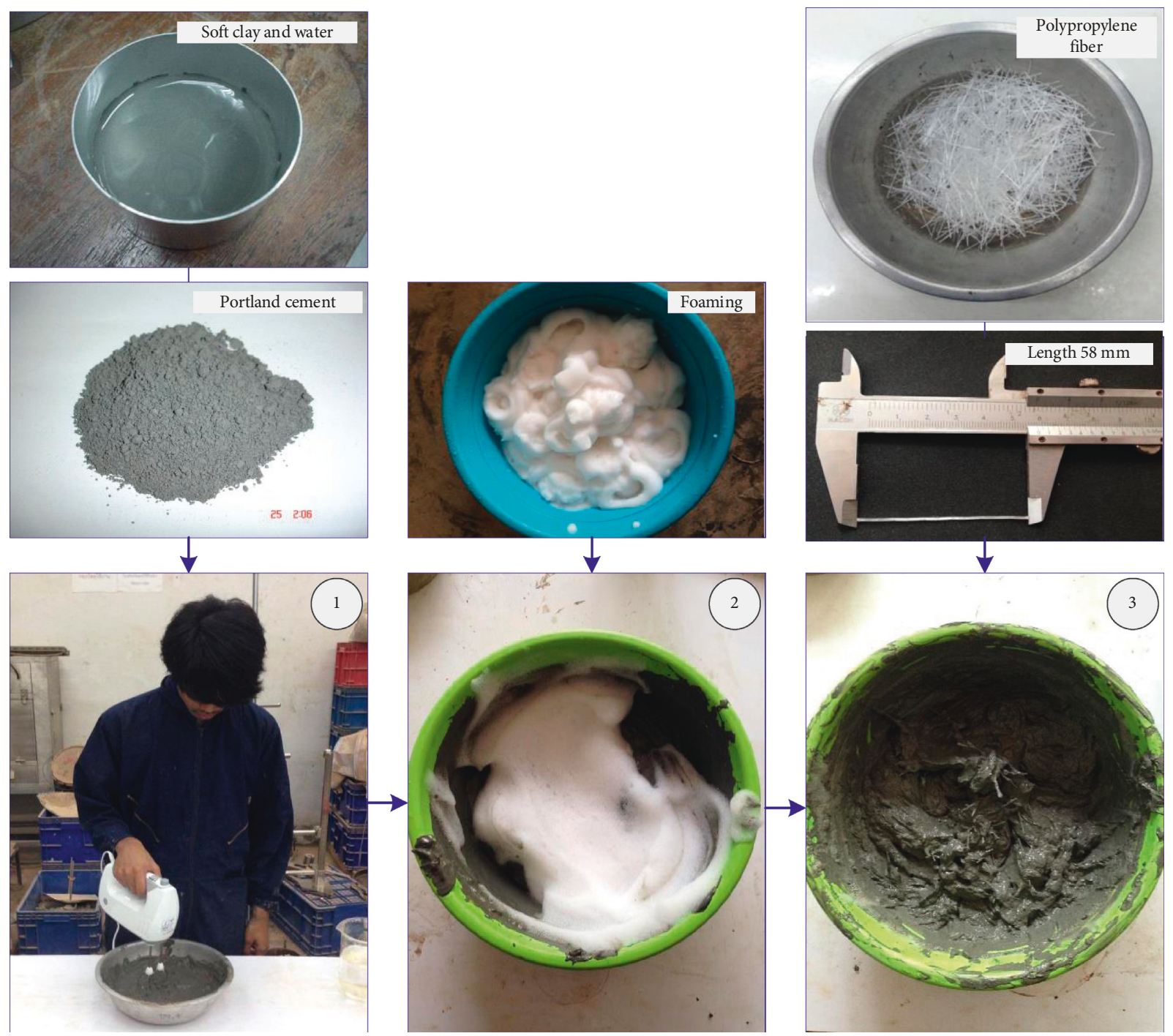

FIGURE 1: Schematic photographs of the mixing procedure.

and the range of flowability values for the flow test was between 16 and $20 \mathrm{~cm}$ [39]. Since the foam has water, the overall water content of the clay-water-cement-foam just after the time of mixing was the total remolding water plus the water in the foam. For the soil cement, the total clay water content $\left(C_{\mathrm{w}}\right)$ and the total clay water content $\left(C_{\mathrm{w}}\right)$ of air-cement-treated soil can be adapted by the relation in equation (2). The overall water content in the mixture is hereinafter called the mixing water content or the total clay water content $\left(C_{\mathrm{w}}\right)$. The total clay water content $\left(C_{\mathrm{w}}\right)$ is defined as follows:

$$
C_{\mathrm{w}}=w^{*}+\left(\frac{w}{w_{\mathrm{F}}}\right) F_{\mathrm{w}}
$$

where $C_{\mathrm{w}}, w^{*}, w / w_{\mathrm{F}}$, and $F_{\mathrm{w}}$ are the total clay water content (or mixing water content) of the clay-water-cement-fly ash- 
foam paste (\%) from the dry weight of soil only, the remolding clay water content (\%) before mixing the cement and foam, the water-foam material ratio, and the desired foam (\%), which is defined as the percentage ratio of the weight of foam to the dry weight of soil. The overall aircement-treated soil preparation for the entire study consisted of $300 \%$ remolding water content at the initial state in all mixtures and at controlled densities of $0.8,1.0$, and $1.2 \mathrm{~g} /$ $\mathrm{cm}^{3}$. The cement content, $A_{\mathrm{w}}$, is defined as 100,150 , and 200 (kg) in $1 \mathrm{~m}^{3}$ of air foam-cement-admixed clay. The details of the experimental program are presented in Table 2. The specimen with a density of $0.8 \mathrm{~g} / \mathrm{cm}^{3}$, cement content of $100 \mathrm{~kg} / \mathrm{m}^{3}$, and fiber content of $1 \%$ is represented by $0.8 \mathrm{C} 100 \mathrm{~F} 1$ as the test code in this study. According to Miller and Rifai [40], polypropylene has a relatively high melting point, low thermal and electrical conductivity, and a high ignition point, with a specific gravity of 0.91 . It is also a hydrophobic and chemically inert material that does not absorb or react with soil moisture or leachate. In this study, the polypropylene fiber was prepared with a length of $58 \mathrm{~mm}$ and used in the study at three different volume fractions: $0.5 \%, 0.75 \%$, and $1 \%$.

3.2. Flexural Performance Test. After curing for 28 days, the dimensions of the specimens were measured, and all variations in width, height, and length were satisfactory. The flexural performance test was conducted in accordance with the ASTM C1609 standard [41]. This standard is a specification governing the testing of fiber-reinforced concrete beams conducted on a beam with third-point loading (Figure 2). The test is run at a specified net deflection rate to a net deflection of $L / 600$ (where $L$ is the support span distance). It can then be run at a higher specified net deflection rate until the specified endpoint.

To better understand the relative influence of the fiber content, in this study, the term equivalent flexural strength ratio was used to describe the efficiency of fiber inclusion on the engineering characteristics of LFS, for both deflection softening and deflection hardening. This index provides the determination of specimen toughness based on the area under the load-deflection curve up to the prescribed deflection, as depicted in Figure 3. The flexural strength $(f)$ can be expressed as follows:

$$
f=\frac{P L}{b d^{2}}
$$

where $P$ is the load $(\mathrm{kN})$ corresponding to $L, b$, and $d$ which are span length, width, and depth of the specimen, respectively. For the deflection softening (gray line), the first peak load $\left(P_{1}\right)$ is defined as the peak load $\left(P_{\mathrm{p}}\right)$ and corresponds to the deflection value $\delta_{\mathrm{p}}$. For numerical purposes, $P_{1}$ is appropriately defined as the first crack point $[25,42,43]$. To assess the ductility of LFS, the ductility index (DI) in the approach proposed by Nematollahi et al. [43] is used and referred to as DI $=\left(\delta_{\mathrm{p}} / \delta_{1}\right)$, where $\delta_{\mathrm{p}}$ and $\delta_{1}$ are the deflections of the specimen at the peak and first peak, respectively. This index is productive when either the
TABLE 2: Mixed design in the testing program.

\begin{tabular}{|c|c|c|c|}
\hline Name & $\begin{array}{l}\text { Density } \\
\left(\mathrm{g} / \mathrm{cm}^{3}\right)\end{array}$ & $\begin{array}{l}\text { Cement } \\
\text { content } \\
\left(\mathrm{kg} / \mathrm{m}^{3}\right)\end{array}$ & Fiber content (\%) \\
\hline $0.8 \mathrm{C} 100 \mathrm{~F} 0$ & 0.8 & 100 & 0 \\
\hline 0.8C150F0 & 0.8 & 150 & 0 \\
\hline $0.8 \mathrm{C} 200 \mathrm{~F} 0$ & 0.8 & 200 & 0 \\
\hline $0.8 \mathrm{C} 100 \mathrm{~F} 0.5$ & 0.8 & 100 & 0.5 \\
\hline $0.8 \mathrm{C} 150 \mathrm{~F} 0.5$ & 0.8 & 150 & 0.5 \\
\hline $0.8 \mathrm{C} 200 \mathrm{~F} 0.5$ & 0.8 & 200 & 0.5 \\
\hline $0.8 \mathrm{C} 100 \mathrm{~F} 0.75$ & 0.8 & 100 & 0.75 \\
\hline $0.8 \mathrm{C} 150 \mathrm{~F} 0.75$ & 0.8 & 150 & 0.75 \\
\hline $0.8 \mathrm{C} 200 \mathrm{~F} 0.75$ & 0.8 & 200 & 0.75 \\
\hline $0.8 \mathrm{C} 100 \mathrm{~F} 1$ & 0.8 & 100 & 1 \\
\hline $0.8 \mathrm{C} 150 \mathrm{~F} 1$ & 0.8 & 150 & 1 \\
\hline $0.8 \mathrm{C} 200 \mathrm{~F} 1$ & 0.8 & 200 & 1 \\
\hline 1C100F0 & 1 & 100 & 0 \\
\hline 1C150F0 & 1 & 150 & 0 \\
\hline $1 \mathrm{C} 200 \mathrm{~F} 0$ & 1 & 200 & 0 \\
\hline 1C100F0.5 & 1 & 100 & 0.5 \\
\hline 1C150F0.5 & 1 & 150 & 0.5 \\
\hline 1C200F0.5 & 1 & 200 & 0.5 \\
\hline 1C100F0.75 & 1 & 100 & 0.75 \\
\hline 1C150F0.75 & 1 & 150 & 0.75 \\
\hline 1C200F0.75 & 1 & 200 & 0.75 \\
\hline $1 \mathrm{C} 100 \mathrm{~F} 1$ & 1 & 100 & 1 \\
\hline 1C150F1 & 1 & 150 & 1 \\
\hline $1 \mathrm{C} 200 \mathrm{~F} 1$ & 1 & 200 & 1 \\
\hline $1.2 \mathrm{C} 100 \mathrm{~F} 0$ & 1.2 & 100 & 0 \\
\hline $1.2 \mathrm{C} 150 \mathrm{~F} 0$ & 1.2 & 150 & 0 \\
\hline $1.2 \mathrm{C} 200 \mathrm{~F} 0$ & 1.2 & 200 & 0 \\
\hline $1.2 \mathrm{C} 100 \mathrm{~F} 0.5$ & 1.2 & 100 & 0.5 \\
\hline $1.2 \mathrm{C} 150 \mathrm{~F} 0.5$ & 1.2 & 150 & 0.5 \\
\hline $1.2 \mathrm{C} 200 \mathrm{~F} 0.5$ & 1.2 & 200 & 0.5 \\
\hline $1.2 \mathrm{C} 100 \mathrm{~F} 0.75$ & 1.2 & 100 & 0.75 \\
\hline $1.2 \mathrm{C} 150 \mathrm{~F} 0.75$ & 1.2 & 150 & 0.75 \\
\hline $1.2 \mathrm{C} 200 \mathrm{~F} 0.75$ & 1.2 & 200 & 0.75 \\
\hline $1.2 \mathrm{C} 100 \mathrm{~F} 1$ & 1.2 & 100 & 1 \\
\hline $1.2 \mathrm{C} 150 \mathrm{~F} 1$ & 1.2 & 150 & 1 \\
\hline $1.2 \mathrm{C} 200 \mathrm{~F} 1$ & 1.2 & 200 & 1 \\
\hline
\end{tabular}

first peak strength or the overall peak strength is clearly observed.

To evaluate the flexural toughness of LFS with different fiber contents, the flexural toughness $\left(T_{150}^{\mathrm{D}}\right)$ is calculated by the total area under the load-deflection curve corresponding to specified deflection of $L / 150$ as shown in Figure 3. After obtaining the toughness capacity of LFS, the equivalent flexural strength $\left(R_{\mathrm{T}, 150}^{\mathrm{D}}\right)$ ratio indicates the flexural performance or ability to persist a large deformation of LFS upon axial compression until $10 \%$. This concept is applied herein to quantify the flexural strength, and $R_{\mathrm{T}, 150}^{\mathrm{D}}$ can be determined as follows:

$$
R_{\mathrm{T}, 150}^{\mathrm{D}}=\frac{T_{150}^{\mathrm{D}}}{P_{1}(L / 150)} \times 100 \% .
$$

Zone I: $R_{\mathrm{T}, 150}^{\mathrm{D}}<100 \% ; P_{1}=P_{\mathrm{p}}$; low toughness Zone II: $R_{\mathrm{T}, 150}^{\mathrm{D}}>100 \% ; P_{1}<P_{\mathrm{p}}$; high toughness 


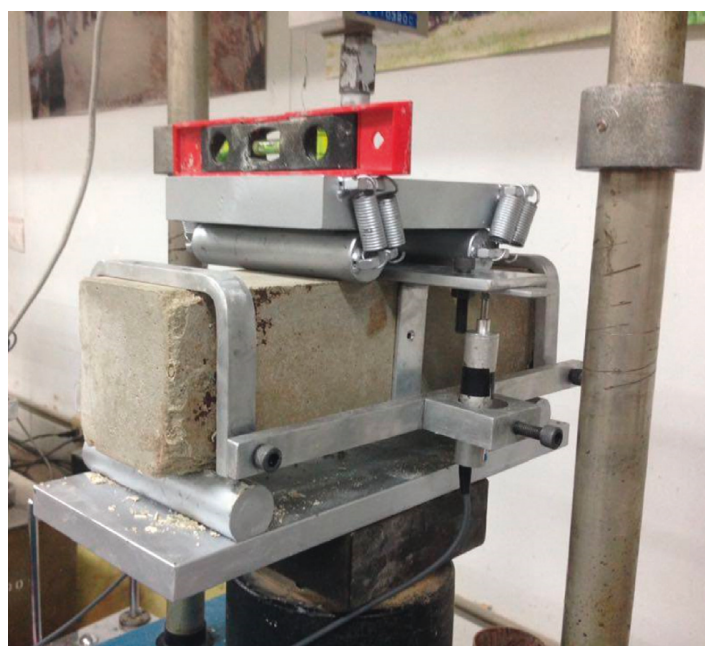

(a)

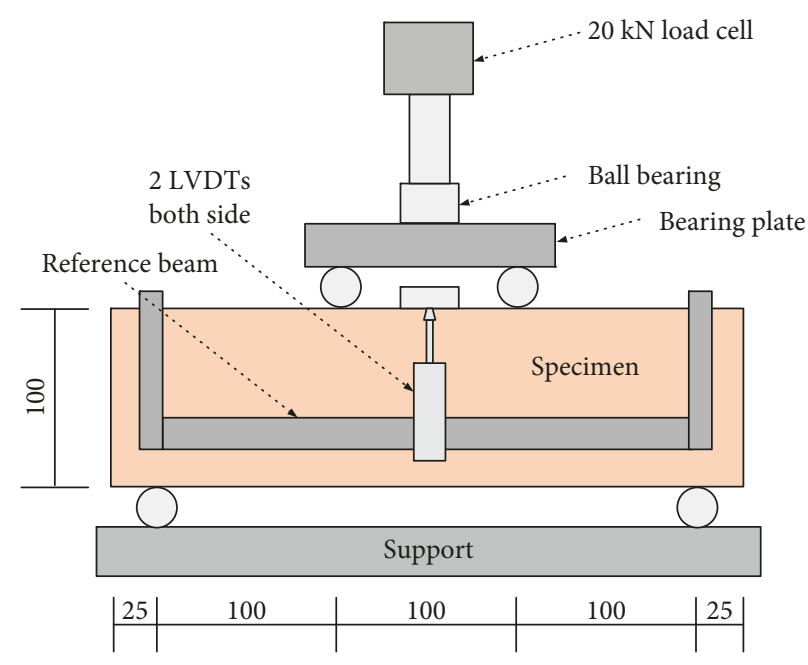

(b)

Figure 2: Photograph and schematic of the (a) experimental device and (b) specimen setup.

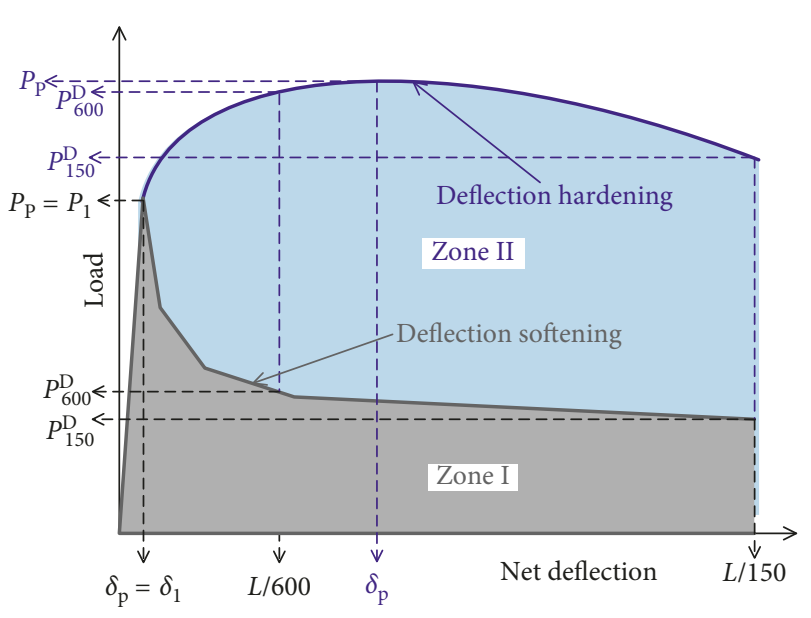

FIgURE 3: Definition of the load-net deflection curve from the flexural performance test (ASTM C1609) and the equivalent flexural strength ratio.

\section{Results and Discussion}

As shown in Figure 4(a), the increase in cement content contributes to the increase in the flexural strength of LFS. The flexural strength also increased as the density increased. The unreinforced specimen typically showed brittle failure. With those unreinforced specimens, after reaching peak stress, failure occurred suddenly and was accompanied by a large single crack development under the sample, as depicted in Figure 4(b). The initial crack was observed from a very early stage in the load-deflection response of the entire specimen. Figure 4(b) presents the plot of $\delta_{\mathrm{p}}$ and cement content for unreinforced specimens, where $\delta_{\mathrm{p}}$ was found to decrease with a decrease in density and an increase in the cement content. It is possible that the LFS material tends to be more brittle due to the addition of void and cement content.

The effects of fiber content, cement contents, and densities on flexural strength and deformation characteristics of lightweight foam mixed soil were evaluated by conducting a series of flexural strength tests as shown in Figures 5(a)-5(i). As observed from Figures 5(a)-5(i), the peak flexural strength for all unreinforced specimens was achieved at a small value of deformation (approximately, at $\delta_{\mathrm{p}}<0.2 \mathrm{~mm}$ ). All LFS specimens exhibit a low energy absorption ability. Fiber addition to LFS is known to change the behavior from brittle to a more ductile one. With the contribution of fiber, LFS can withstand strains compared to unreinforced specimens. The fiber inclusion is more efficient in highdensity specimens, with few exceptions. It can be inferred that all test specimens have similar flexural strength behavior with respect to the inclusion of fiber content. The rate of flexural strength decreases with increasing fiber content. The maximum value for the first peak was measured to be $630 \mathrm{kPa}$ within $1.0 \mathrm{C} 200 \mathrm{~F} 1$. One feature observed from Figure 5 is that the $f_{\mathrm{p}}$ values are higher than $f_{1}$ for the high fiber inclusion specimens, for instance, $0.8 \mathrm{C} 100 \mathrm{~F} 1$, $0.8 \mathrm{C} 200 \mathrm{~F} 1$, and $1.0 \mathrm{C} 100 \mathrm{~F} 1$. For the unreinforced specimens, a sudden failure is observed. According to all test results, the flexural characteristics of LFS were enhanced by fiber addition, both of the peak and residual flexural strength $\left(f_{\mathrm{s}}\right)$. As observed, although the reinforced samples show a significant increase in the flexural performance, the fiber inclusion does not improve their stiffness. In the case of cement content $=100 \mathrm{~kg} / \mathrm{m}^{3}$, the fiber content of $0.5 \%$ samples show that their stiffness is lower than that of the unreinforced samples. In Figures 5(b), 5(c), 5(e), 5(f), 5(h), and $5(\mathrm{i})$, the stiffness of reinforced samples does not appear to depend on the amount of fiber inclusion.

Figures 6(a)-6(d) show the variation in flexural strength values with the proportions of density, cement content, and fiber content. By increasing the amount of cement content and density, $f_{1}$ and $f_{\mathrm{p}}$ increase for all reinforced and unreinforced samples as depicted in Figures 6(a) and 6(b). The trend in the inclusion of polypropylene fiber was found to be $f_{1}$ and $f_{\mathrm{p}}$ increasing with increasing fiber content. The presence of fiber (especially 1\%) led to a maximum almost 4 


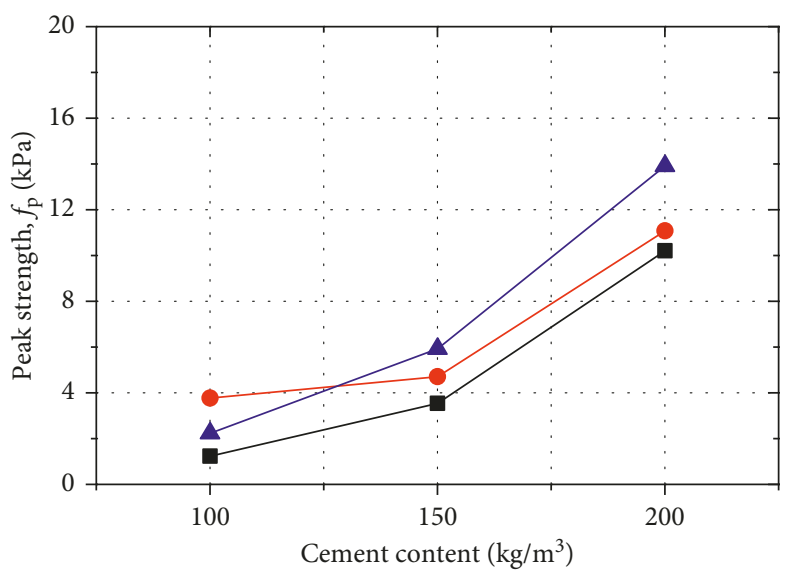

$-0.8 \mathrm{~g} / \mathrm{cm}^{3}$

- $1.0 \mathrm{~g} / \mathrm{cm}^{3}$

$-1.2 \mathrm{~g} / \mathrm{cm}^{3}$

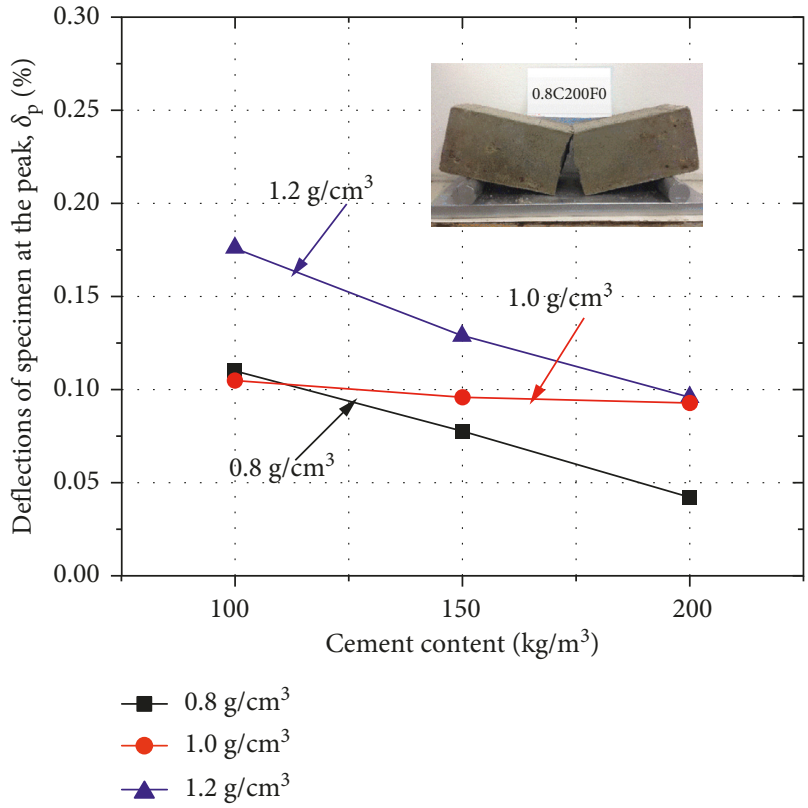

(b)

FIgURE 4: Effect of cement content at different densities: (a) peak strength; (b) deflections of specimens at the peak.

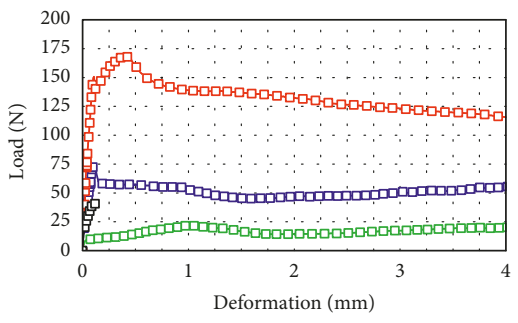

$\longrightarrow$ - $0.8 \mathrm{C} 100 \mathrm{~F} 0 \quad \longrightarrow-0.8 \mathrm{C} 100 \mathrm{~F} 0.75$

$\square-0.8 \mathrm{C} 100 \mathrm{~F} 0.5 \longrightarrow 0.8 \mathrm{C} 100 \mathrm{~F} 1.0$

(a)

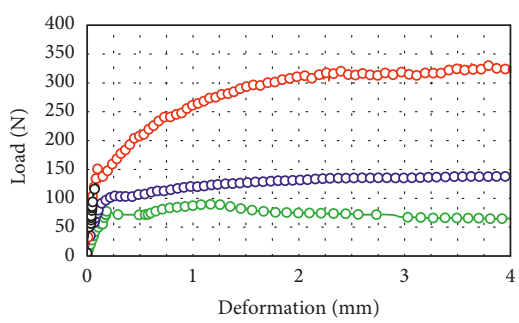

$\multimap 1.0 \mathrm{C} 100 \mathrm{~F} 0 \quad-1.0 \mathrm{C} 100 \mathrm{~F} 0.75$

$\multimap$ 1.0C100F $0.5 \quad \multimap 1.0 \mathrm{C} 100 \mathrm{~F} 1.0$

(d)

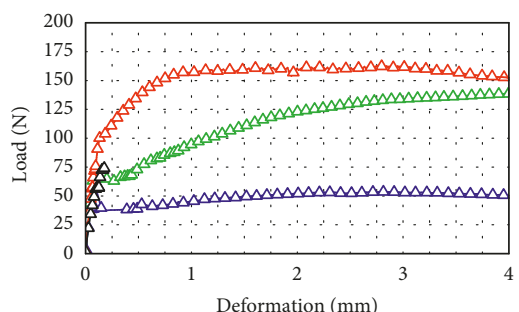

$\neg \quad 1.2 \mathrm{C} 100 \mathrm{~F} 0 \quad \longrightarrow \quad 1.2 \mathrm{C} 100 \mathrm{~F} 0.75$

$\triangle 1.2 \mathrm{C} 100 \mathrm{~F} 0.5 \quad \triangle-1.2 \mathrm{C} 100 \mathrm{~F} 1.0$

(g)

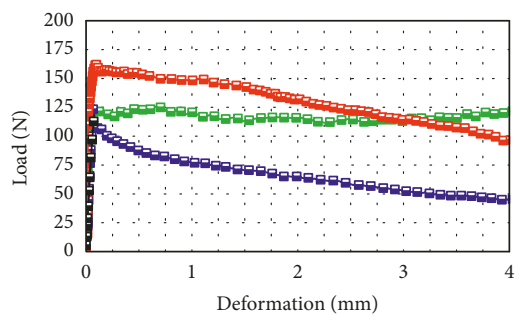

$\square 0.8 \mathrm{C} 150 \mathrm{~F} 0 \longrightarrow 0.8 \mathrm{C} 150 \mathrm{~F} 0.75$

(b)

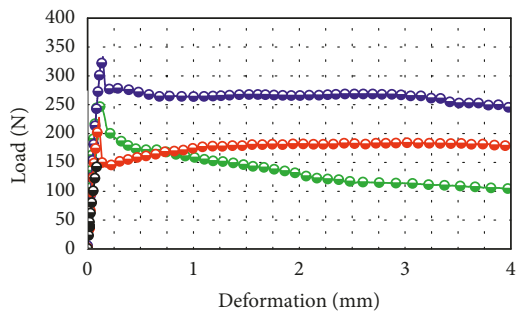

$\multimap 1.0 \mathrm{C} 150 \mathrm{~F} 0 \quad 1.0 \mathrm{C} 150 \mathrm{~F} 0.75$

$\begin{array}{llll}\longrightarrow & 1.0 \mathrm{C} 150 \mathrm{~F} 0 & \longrightarrow & 1.0 \mathrm{C} 150 \mathrm{~F} 0.75 \\ -1.0 \mathrm{C} 150 \mathrm{~F} 0.5 & \longrightarrow & 1.0 \mathrm{C} 150 \mathrm{~F} 1.0\end{array}$

(e)

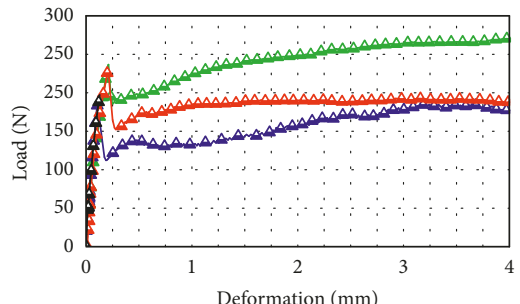

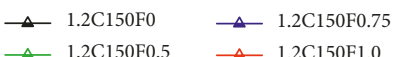

(h)

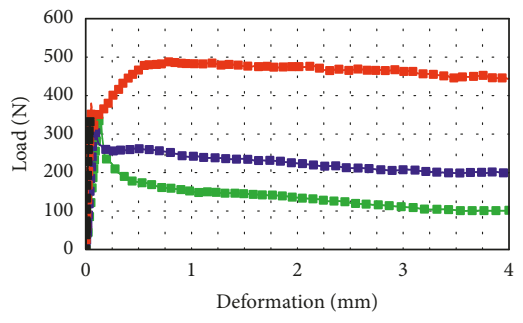

$\rightarrow-0.8 \mathrm{C} 200 \mathrm{~F} 0 \rightarrow 0.8 \mathrm{C} 200 \mathrm{~F} 0.75$

(c)

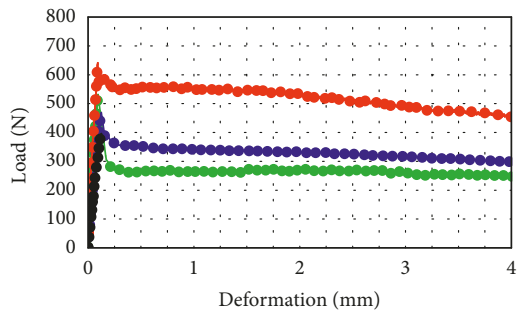

$\longrightarrow \quad 1.0 \mathrm{C} 200 \mathrm{~F} 0 \quad \longrightarrow \quad 1.0 \mathrm{C} 200 \mathrm{~F} 0.75$

$\multimap 1.0 \mathrm{C} 200 \mathrm{~F} 0.5 \longrightarrow 1.0 \mathrm{C} 200 \mathrm{~F} 1.0$

(f)

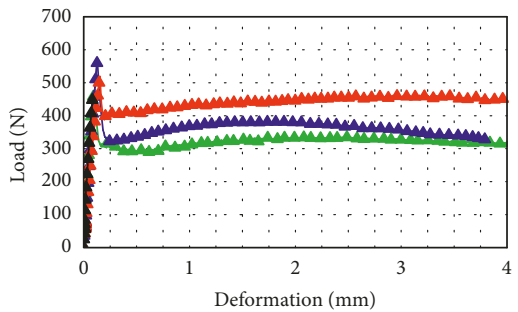

$\leftarrow 1.2 \mathrm{C} 200 \mathrm{~F} 0 \longrightarrow 1.2 \mathrm{C} 200 \mathrm{~F} 0.75$

(i)

Figure 5: (a-i) Typical flexural curves of specimens with different fiber contents. 


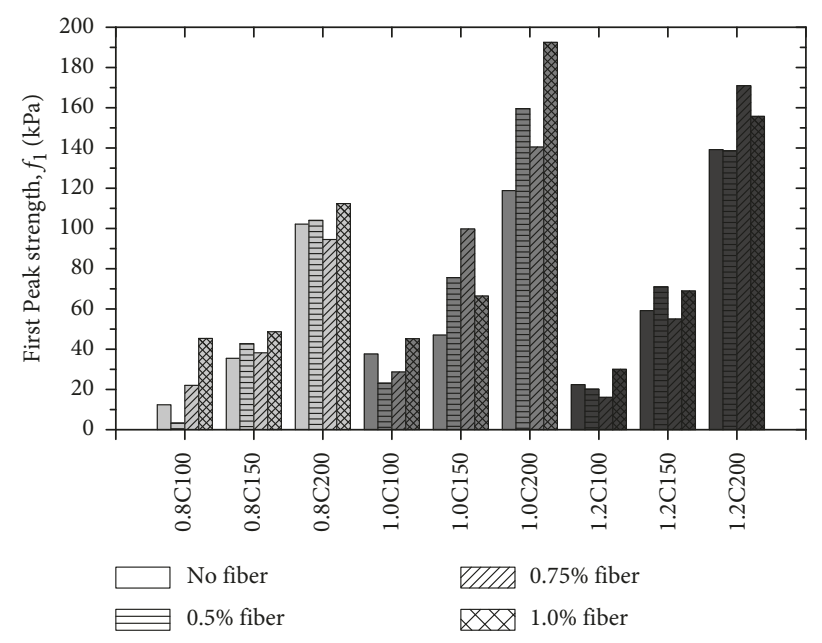

(a)

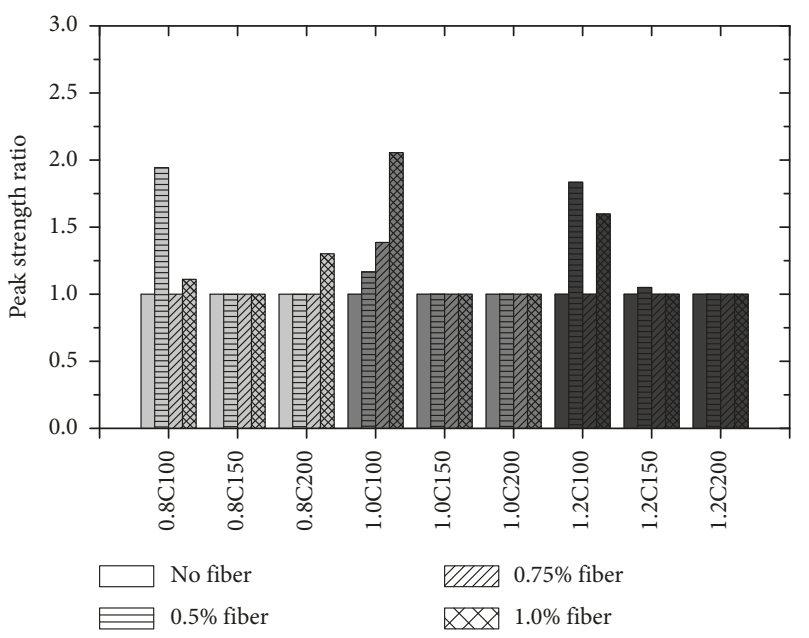

(c)

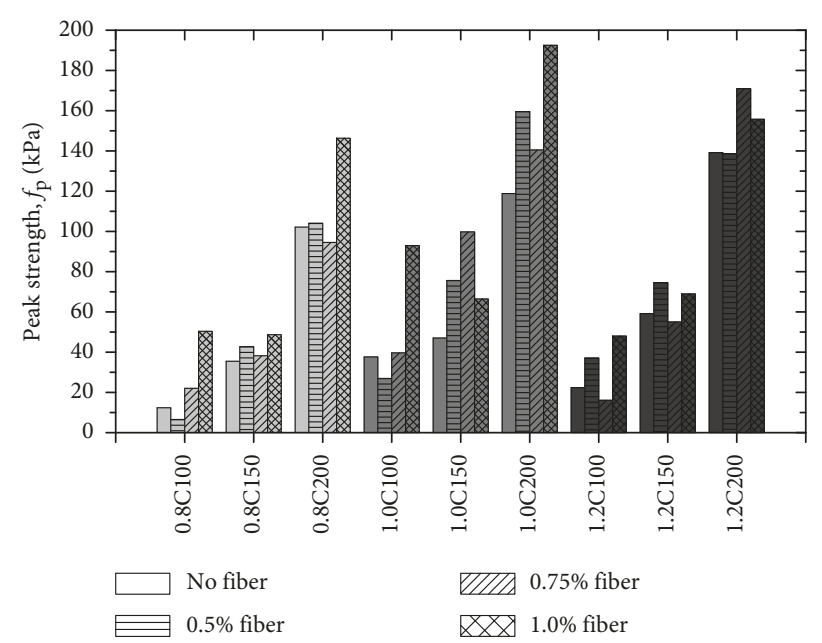

(b)

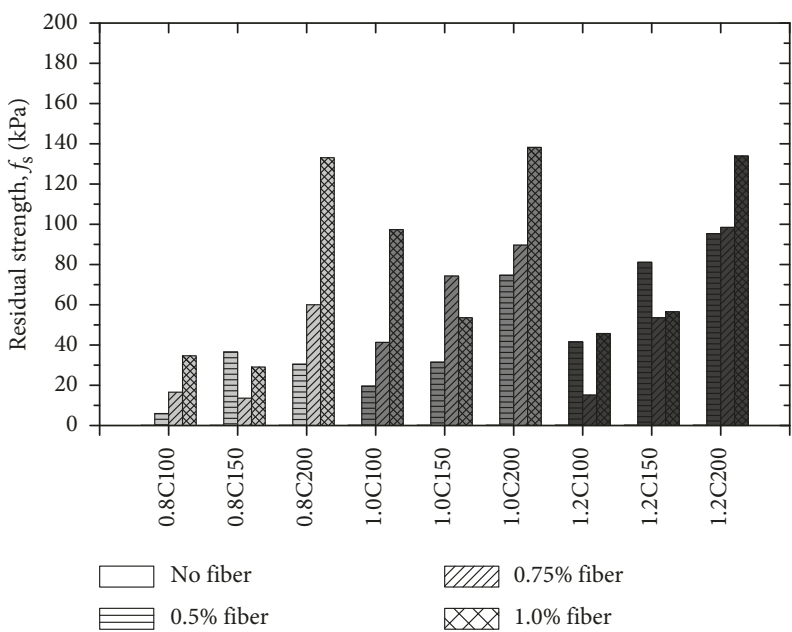

(d)

FiguRE 6: Effect of fiber content on the flexural performance of LFS: (a) first peak strength; (b) peak strength; (c) peak strength ratio; (d) residual flexural strength.

times larger than in the $f_{\mathrm{p}}$ of the unreinforced sample. However, as shown in Figures 6(a) and 6(b), it appears that a decrease in $f_{1}$ and $f_{\mathrm{p}}$ is visible in the lowest cement content samples with the inclusion of $0.5 \%-0.75 \%$ (i.e., $0.8 \mathrm{C} 100 \mathrm{~F} 0.5$, $1.0 \mathrm{C} 100 \mathrm{~F} 0.5$, and $1.2 \mathrm{C} 100 \mathrm{~F} 0.75)$. The peak strength ratio is defined as $f_{\mathrm{p}}$ divided by $f_{1}$ as shown in Figure 6(c). According to Khelifi et al. [44], $f_{1}$ directly corresponds to matrix failure. Therefore, the presence of fiber may affect the postpeak behaviors, as shown in the improvement compared to the unreinforced specimens. The ratio may indicate the effect of fiber existence, which can be used to improve the ductility or deformability of LFS. It was found that, by the inclusion of fiber, there was a remarkable effect on the lightly cemented samples. The peak strength ratio is almost the same when the cement content is increased. Figure 6(d) shows that a more pronounced residual strength is obtained in the case of high fiber content. For the unreinforced specimens, the residual flexural strength was found to be $0 \mathrm{kPa}$ (sudden failure), as has been previously mentioned.
In terms of the ductility index $\left(\mathrm{DI}=\left(\delta_{\mathrm{p}} / \delta_{1}\right)\right)$, it is evident that the DI values of lowest cement content were higher than those with cement content $=150$ and $200 \mathrm{~kg} / \mathrm{m}^{3}$, as depicted in Figure 7(a). The increase in ductility index for the mixture with cement content $=100 \mathrm{~kg} / \mathrm{m}^{3}$ is remarkably increased with the density. As expected, almost all samples with high cement content exhibited DI $=1$. It is likely that fiber does not contribute to increasing DI when the cement content is 150 and $200 \mathrm{~kg} / \mathrm{m}^{3}$, which produced softening behavior. To reflect the toughness behavior, Figure $7(\mathrm{~b})$ shows the variations of $T_{150}^{\mathrm{D}}$ corresponding to a given set of testing programs. The results illustrate that more fiber in all mixtures results in a higher tendency of $T_{150}^{\mathrm{D}}$. However, the effect of cement content has an insignificant impact on the variation of $T_{150}^{\mathrm{D}}$. Figure $7(\mathrm{c})$ shows the relationship between $R_{\mathrm{T}, 150}^{\mathrm{D}}$ and fiber content at different densities and cement contents. These figures illustrate that a more pronounced toughness behavior is obtained with decreasing cement content and increasing density specimens. A high 


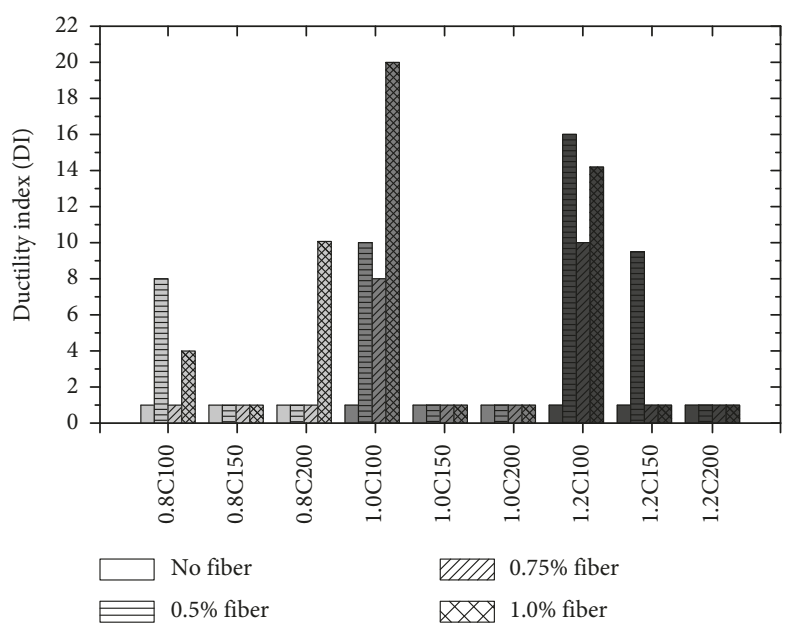

(a)

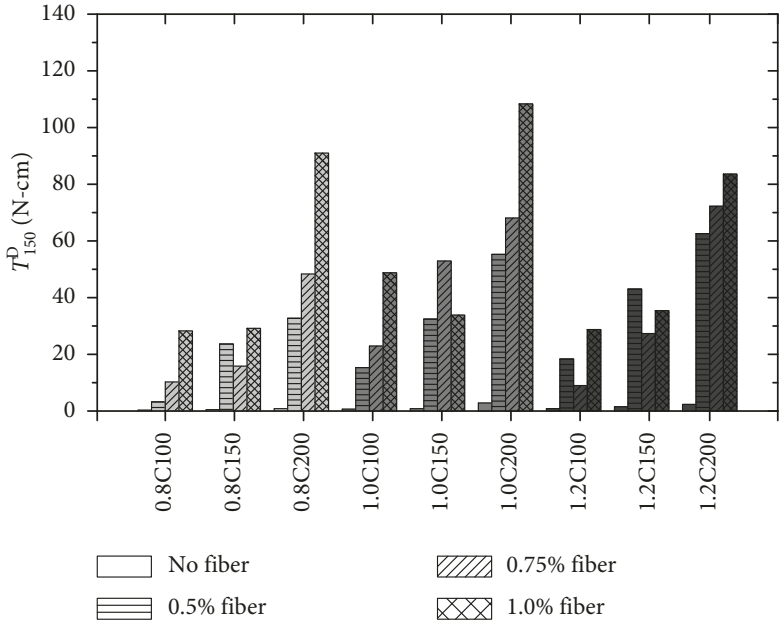

(b)

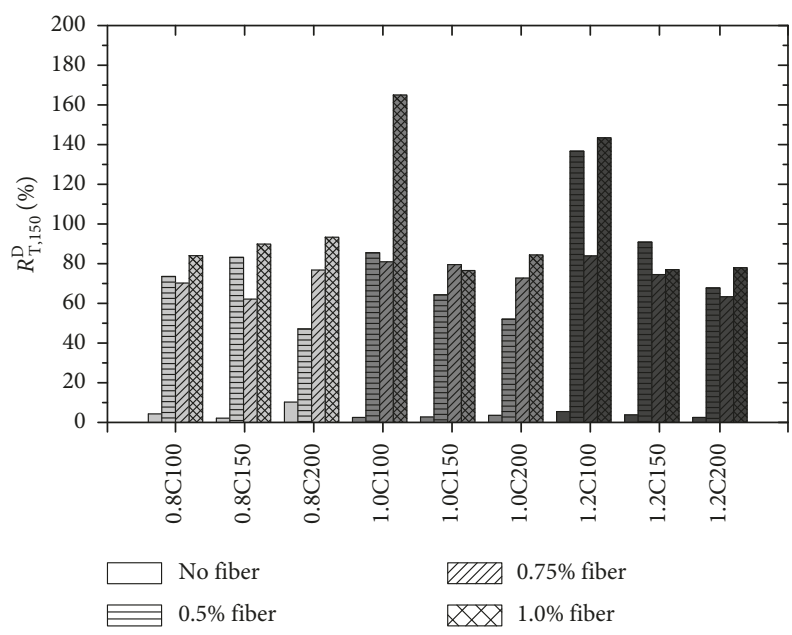

(c)

Figure 7: Effect of fiber content on (a) DI, (b) $T_{150}^{\mathrm{D}}$, and (c) $R_{\mathrm{T}, 150}^{\mathrm{D}}$.

toughness behavior $\left(R_{\mathrm{T}, 150}^{\mathrm{D}}>100 \%\right)$ is found (specimens 1.0C100F1.0, 1.2C100F0.5, and 1.2C100F1.0), as evident from Figures 5(g) and 5(h). Referring to Figure 5, it can be seen that by reinforcing, different peak and residual strengths (deflection hardening and deflection softening) were obtained. The trend of deflection hardening is noticeably larger for the high-density and low-cement content specimens (e.g., 1.2C100F1.0, 1.2C100F0.75, and 1.2C150F0.5) due to the dominant effects of fiber inclusion. It can be concluded that the efficiency of fiber has a positive influence on the toughness behavior with increasing density and decreasing cement content, barring a few exceptions.

To evaluate the test results, the concept of overall performance was applied to incorporate the performance of LFS reinforcement on flexural behaviors. The concept of overall performance was developed by Jamsawang et al. [26] as an appropriate parameter to evaluate the flexural performance of compacted cement-fiber-sand (CCFS). To achieve the best overall performance rating, six subperformance values were used: (1) first peak strength $\left(f_{1}\right),(2)$ peak strength $\left(f_{\mathrm{p}}\right),(3)$ residual strength $\left(f_{\mathrm{s}}\right),(4)$ ductility index (DI), (5) flexural toughness at deflection of $L / 150\left(T_{150}^{\mathrm{D}}\right)$, and (6) equivalent flexural strength ratio $\left(R_{\mathrm{T}, 150}^{\mathrm{D}}\right)$. After obtaining each subperformance value, the average subperformance value at each density and cement content, as shown in Table 3, is calculated using the following equation:

average subperformance value

$$
=\frac{\text { sum of performance value }}{\text { number of fiber contents }} \times 100 \text {. }
$$

Based on the obtained values of the average subperformance value, the comparative score average subperformance value can be calculated with a maximum score of 100 for each cement content using the following formula: comparative score

$$
=\frac{\text { average sub performance value }}{\text { best average subperformance value for each cement content }} \times 100 \text {. }
$$

As depicted in Table 4, for comparison, the values of $f_{1}$ for subperformance with a cement content of $100 \mathrm{~kg} / \mathrm{m}^{3}$ for 
TABle 3: Average subperformance values of LFS.

\begin{tabular}{|c|c|c|c|c|c|c|}
\hline \multirow{2}{*}{ Sample } & \multicolumn{6}{|c|}{ Average subperformance value } \\
\hline & $f_{1}(\mathrm{kPa})$ & $f_{\mathrm{p}}(\mathrm{kPa})$ & $f_{\mathrm{s}}(\mathrm{kPa})$ & DI & $T_{150}^{\mathrm{D}}(\mathrm{N}-\mathrm{m})$ & $R_{\mathrm{T}, 150}^{\mathrm{D}}(\%)$ \\
\hline $0.8 \mathrm{C} 100$ & 23.56 & 26.30 & 19.07 & 4.33 & 13.90 & 75.93 \\
\hline $1.0 \mathrm{C} 100$ & 32.32 & 53.20 & 52.73 & 12.67 & 22.91 & 78.44 \\
\hline $1.2 \mathrm{C} 100$ & 22.08 & 33.67 & 34.10 & 13.40 & 57.35 & 72.40 \\
\hline $0.8 \mathrm{C} 150$ & 43.20 & 43.20 & 26.37 & 1.00 & 28.99 & 110.49 \\
\hline $1.0 \mathrm{C} 150$ & 80.62 & 80.62 & 53.10 & 1.00 & 39.73 & 73.44 \\
\hline $1.2 \mathrm{C} 150$ & 64.98 & 66.17 & 63.73 & 3.83 & 77.24 & 69.70 \\
\hline $0.8 \mathrm{C} 200$ & 103.64 & 114.94 & 74.53 & 4.02 & 18.68 & 121.33 \\
\hline $1.0 \mathrm{C} 200$ & 164.17 & 164.17 & 100.83 & 1.00 & 35.24 & 80.78 \\
\hline $1.2 \mathrm{C} 200$ & 155.10 & 155.10 & 109.20 & 1.00 & 72.79 & 70.52 \\
\hline
\end{tabular}

TABLE 4: Comparative score of the subperformance of LFS based on a full score of 100 points.

\begin{tabular}{|c|c|c|c|c|c|c|}
\hline \multirow{2}{*}{ Sample } & \multicolumn{6}{|c|}{ Subperformance of LFS } \\
\hline & $f_{1}$ (point) & $f_{\mathrm{p}}($ point $)$ & $f_{\mathrm{s}}($ point $)$ & DI (point) & $T_{150}^{\mathrm{D}}$ (point) & $R_{\mathrm{T}, 150}^{\mathrm{D}}($ point $)$ \\
\hline $0.8 \mathrm{C} 100$ & 73 & 49 & 36 & 32 & 24 & 97 \\
\hline $1.0 \mathrm{C} 100$ & 100 & 100 & 100 & 95 & 40 & 100 \\
\hline $1.2 \mathrm{C} 100$ & 68 & 63 & 65 & 100 & 100 & 93 \\
\hline $0.8 \mathrm{C} 150$ & 54 & 54 & 41 & 26 & 38 & 100 \\
\hline $1.0 \mathrm{C} 150$ & 100 & 100 & 83 & 26 & 51 & 67 \\
\hline $1.2 \mathrm{C} 150$ & 81 & 82 & 100 & 100 & 100 & 63 \\
\hline $0.8 \mathrm{C} 200$ & 63 & 70 & 68 & 100 & 26 & 100 \\
\hline $1.0 \mathrm{C} 200$ & 100 & 100 & 92 & 25 & 48 & 67 \\
\hline $1.2 \mathrm{C} 200$ & 95 & 95 & 100 & 25 & 100 & 58 \\
\hline
\end{tabular}

the samples $0.8 \mathrm{C} 100,1.0 \mathrm{C} 100$, and $1.2 \mathrm{C} 100$ are 23.56, 32.32 , and $22.08 \mathrm{kPa}$, respectively. The comparative score for the subperformance value is the subperformance value of each value divided by the maximum value for this category $\left(f_{1}=32.32 \mathrm{kPa}\right)$. In this study, the overall performance of LFS is defined as follows:

percentage of overall performance

$$
=\frac{\text { sum of score of subperformance }}{\text { sum of full score of subperformance }} \times 100 \text {. }
$$

The percentage of overall performance is used to account for a specific application in the design process. From the present test results, with the addition of polypropylene fiber, the overall performance values increase with increasing density for cement contents of 150 and $200 \mathrm{~kg} / \mathrm{m}^{3}$, respectively. However, for the lowest cement content, the fiber inclusion seems to produce a strong effectiveness at a density of $1.0 \mathrm{~g} / \mathrm{cm}^{3}$. The overall performance rating was divided into seven levels: (1) excellent, (2) very good, (3) good, (4) fairly good, (5) fair, (6) poor, and (7) very poor. Because there was no standard to define these levels, the common concept of significance in geotechnical engineering was adopted, as listed in Table 5. Table 6 shows the ranks of all mixing proportions based on the overall performance of LFS (\%). It can be observed that only sample $1.0 \mathrm{C} 100$ provides excellent overall performance, whereas samples $1.2 \mathrm{C} 150$ and $1.2 \mathrm{C} 100$ show very good performance. In addition, samples 1.2C200, 1.0C200, and 1.0C150 achieved good performance, whereas fair performances were achieved with samples
TABLE 5: Overall performance rating based on the range of average percentages of overall performance.

\begin{tabular}{lc}
\hline $\begin{array}{l}\text { Average percentage of } \\
\text { overall performance }\end{array}$ & $\begin{array}{c}\text { Overall performance } \\
\text { rating }\end{array}$ \\
\hline $90-100$ & Excellent \\
$80-89$ & Very good \\
$70-79$ & Good \\
$60-69$ & Fairly good \\
$50-59$ & Fair \\
$40-49$ & Poor \\
$<39$ & Very poor \\
\hline
\end{tabular}

$0.8 \mathrm{C} 150$ and $0.8 \mathrm{C} 100$. Moreover, some applications may require a specific subperformance rather than an overall performance. As the density increases, there are many more existing contacts of fiber surfaces, products of cement hydration, and particles of soil and interfaces. This results in high forces developed through the interfacial mechanical interactions, and thus, the effectiveness of the fibers is greater [26, 45]. Table 6 can help a designer select the optimal mixing proportion for a specific application.

According to all test results, the deformation characteristics of LFS were enhanced by fiber addition, especially in terms of the loss of postpeak stress. To explain this phenomenon, when local cracks begin to form in the specimen containing fibers, the fibers act as bridges between crack openings, resisting crack development, and the stresses are transferred across by means of fibers in a behavior known as "fiber bridging" [46-48]. The fibers extend from one surface 
TABLE 6: Rank of the effectiveness of each mixing proportion used in this study based on an overall performance rating.

\begin{tabular}{lccc}
\hline Rank & Fiber type & Average percentage of overall performance & Overall performance rating \\
\hline 1 & $1.0 \mathrm{C} 100$ & 90 & Excellent \\
2 & $1.2 \mathrm{C} 150$ & 88 & Very good \\
3 & $1.2 \mathrm{C} 100$ & 81 & Very good \\
4 & $1.2 \mathrm{C} 200$ & 79 & Good \\
5 & $1.0 \mathrm{C} 200$ & 72 & Good \\
6 & $1.0 \mathrm{C} 150$ & 71 & Good \\
6 & $0.8 \mathrm{C} 200$ & 71 & Good \\
7 & $0.8 \mathrm{C} 150$ & 52 & Fair \\
7 & $0.8 \mathrm{C} 100$ & 52 & Fair \\
\hline
\end{tabular}

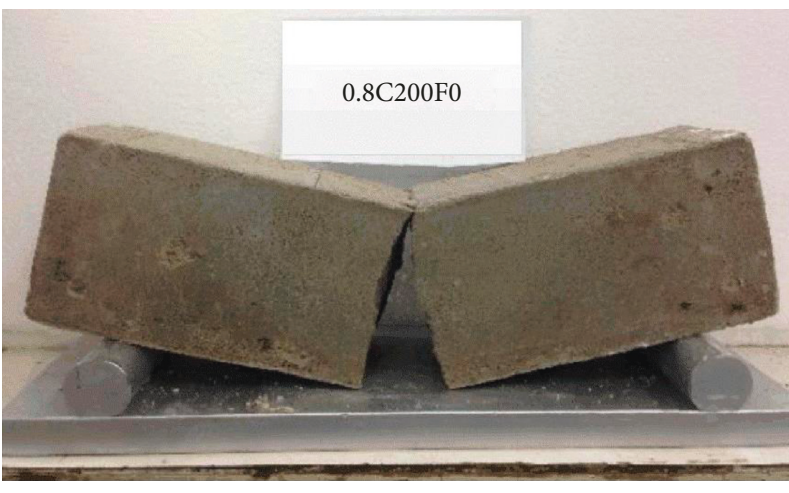

(a)

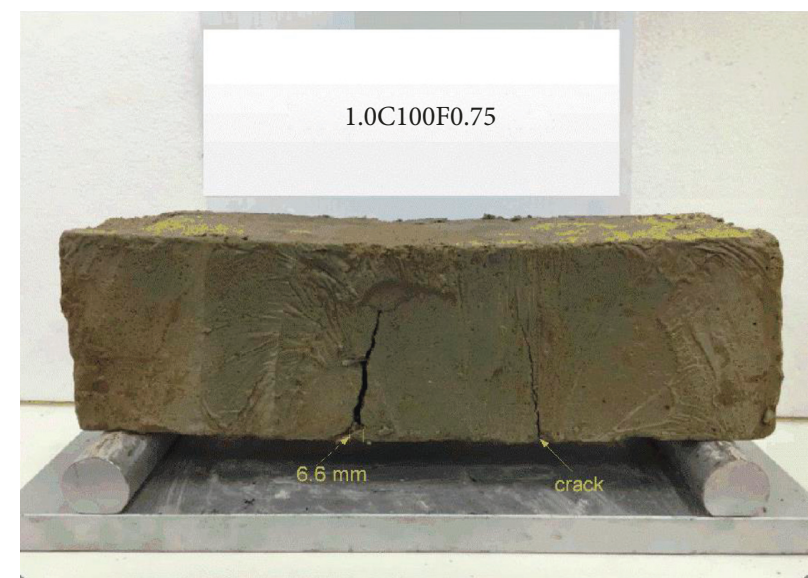

(b)

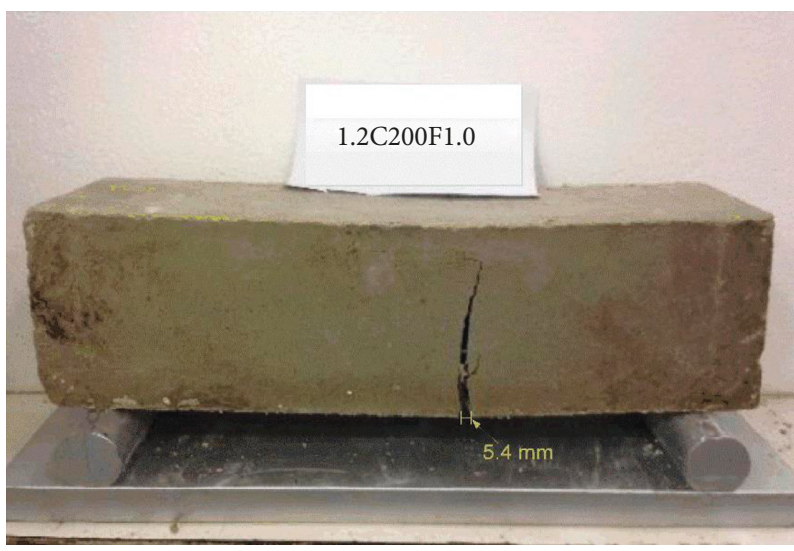

(c)

Figure 8: Photographs of the cracking pattern of specimens.

of the crack to the other and assume a bridging role. Prior to the test, the interfacial mechanical interactions involve the initial binding of the fiber and soil matrix with each other that affect the fiber properties. This results in high forces developed through the interfacial mechanical interactions, and thus, the effectiveness of the fibers is greater. The loss of postpeak is directly related to the propagation of local cracks, which start forming at the peak stress state. The presence of fibers is then likely to obstruct crack propagation, particularly due to the fibers that are perpendicularly aligned to the crack propagation direction. These fibers bear the induced shear stress, and this induced shear stress around the interface begins to exceed the interfacial bond strength at crack formation. The bond force decreases due to the sliding of fibers along the interfacial zone, resulting in a decrease in the rate of softening. As shown in Figure 8, visual observations indicate that the fiber impedes the further development of cracking, resulting in double cracks and smaller crack widths for specimens 1.0C100F0.75 and 1.2C200F1.0, respectively.

\section{Conclusions}

After an experimental investigation of the flexural behaviors of fiber-reinforced lightweight foam mixed soil, polypropylene 
fiber was found to have a significant influence on the flexural behaviors of LFS, and the following conclusions can be drawn:

(i) The flexural strength testing results showed that the contribution of polypropylene fiber to flexural strengths increases the first peak, peak, and residual flexural strengths. The polypropylene fiber improved the flexural strength substantially when compared with the unreinforced specimen. For the fiber inclusion specimens, the first peak, peak, and residual flexural strengths were noted to increase with an increase in density and cement content.

(ii) By increasing the fiber content, the fiber inclusion does not improve the stiffness of LFS. The stiffness of reinforced samples is almost constant and does not appear to be dependent on the amount of fiber inclusion.

(iii) In terms of ductility, the fiber inclusion increased the ductility index significantly for the lowest cement content specimens. For the mixture with a cement content of $100 \mathrm{~kg} / \mathrm{m}^{3}$, the ductility index increases with the density.

(iv) For the toughness behavior, with the contribution of fiber, LFS can withstand larger strains compared to unreinforced specimens. The fiber inclusion is more efficient with an increase in density and decrease in cement content specimens, which resulted in a high toughness behavior $\left(R_{\mathrm{T}, 150}^{\mathrm{D}}>100 \%\right)$.

(v) Based on the conception of overall performance, with the addition of polypropylene fiber, the overall performance values increase with increasing density for cement contents of 150 and $200 \mathrm{~kg} / \mathrm{m}^{3}$. However, for the lowest cement content, the fiber inclusion seems to produce a strong effectiveness at a density of $1.0 \mathrm{~g} / \mathrm{cm}^{3}$.

(vi) The failure mode of LFS with the inclusion of fiber impedes the further development of cracking, which results in noticeable multiple cracks and/or smaller crack widths.

\section{Data Availability}

The data used to support the findings of this study are available from the corresponding author upon request.

\section{Conflicts of Interest}

The authors declare that they have no conflicts of interest regarding the publication of this paper.

\section{Acknowledgments}

This research was funded by the Faculty of Engineering, King Mongkut's University of Technology, North Bangkok, under Grant no. ENG-60-17, and the Department of Civil Engineering, King Mongkut's University of Technology, Thonburi, under Contract no. CE-KMUTT 6221. The last author would like to acknowledge the financial support of the Thailand Research Fund (TRF) under the TRF Distinguished Research Professor Grant no. DPG6180002.

\section{References}

[1] T. Kamei, J.-I. Takashima, and T. Shibi, "Temperature effects on unconfined compressive strength and microstructure of foamed mixture lightweight soil containing flaked polyethylene terephthalate (PET)," Soils and Foundations, vol. 48, no. 6, pp. 833-842, 2008.

[2] Y. Kim, H. Kim, and G. Lee, "Mechanical behavior of lightweight soil reinforced with waste fishing net," Geotextiles and Geomembranes, vol. 26, no. 6, pp. 512-518, 2008.

[3] Y.-J. Kim, J. Hu, S.-J. Lee, and B.-H. You, "Mechanical properties of fiber reinforced lightweight concrete containing surfactant," Advances in Civil Engineering, vol. 2010, Article ID 549642, 8 pages, 2010.

[4] T. E. Frydenlund and R. Aaboe, "Expanded polystyrene-a light way across soft ground," in Proceedings of the 13th ICSMFE, pp. 1287-1292, New Delhi, India, 1993.

[5] J. Otani, T. Mukunoki, and Y. Kikuchi, "Visualization for engineering property of in-situ light weight soils with air foams," Soils and Foundations, vol. 42, no. 3, pp. 93-105, 2002.

[6] T. Tsuchida and K. Egashira, The Lightweight Treated Soil Method: New Geomaterials for Soft Ground Engineering in Coastal Areas, A.A. Balkema Publisher, London, UK, 2004.

[7] Y. Watabe, Y. Itou, M.-S. Kang, and T. Tsuchida, "Onedimensional compression of air-foam treated lightweight geo-material in microscopic point of view," Soils and Foundations, vol. 44, no. 6, pp. 53-67, 2004.

[8] P. Jongpradist, S. Youwai, and C. Jaturapitakkul, "Effective void ratio for assessing the mechanical properties of cementclay admixtures at high water content," Journal of Geotechnical and Geoenvironmental Engineering, vol. 137, no. 6, pp. 621-627, 2011.

[9] C. Teerawattanasuk, P. Voottipruex, and S. Horpibulsuk, "Mix design charts for lightweight cellular cemented Bangkok clay," Applied Clay Science, vol. 104, pp. 318-323, 2015.

[10] P. N. Balaguru and S. P. Shah, Fiber-Reinforced Cement Composites, McGraw-Hill, New York, NY, USA, 1992.

[11] A. J. Puppala and C. Musenda, "Effects of fiber reinforcement on strength and volume change in expansive soils," Transportation Research Record: Journal of the Transportation Research Board, vol. 1736, no. 1, pp. 134-140, 2000.

[12] J. Prabakar and R. S. Sridhar, "Effect of random inclusion of sisal fibre on strength behaviour of soil," Construction and Building Materials, vol. 16, no. 2, pp. 123-131, 2002.

[13] V. C. Li, "Large volume, high-performance applications of fibers in civil engineering," Journal of Applied Polymer Science, vol. 83, no. 3, pp. 660-686, 2002.

[14] K. S. Heineck, M. R. Coop, and N. C. Consoli, "Effect of microreinforcement of soils from very small to large shear strains," Journal of Geotechnical and Geoenvironmental Engineering, vol. 131, no. 8, pp. 1024-1033, 2005.

[15] Z. H. Özkul and G. Baykal, "Shear strength of clay with rubber fiber inclusions," Geosynthetics International, vol. 13, no. 5, pp. 173-180, 2006.

[16] L. Zhang, X. X. Wang, and G. Zheng, "Effect of polypropylene fibers on the strength and elastic modulus of soil-cement," in Proceedings of the 4th Asian Regional Conference on Geosynthetics, vol. 5, pp. 386-391, Shanghai, China, 2008.

[17] Y. Yilmaz, "Compaction and strength characteristics of fly ash and fiber amended clayey soil," Engineering Geology, vol. 188, pp. 168-177, 2015. 
[18] M. Alshaaer, S. A. Mallouh, J. A. Al-Kafawein et al., "Fabrication, microstructural and mechanical characterization of Luffa Cylindrical Fibre - reinforced geopolymer composite," Applied Clay Science, vol. 143, pp. 125-133, 2017.

[19] U. Chaduvula, B. V. S. Viswanadham, and J. Kodikara, "A study on desiccation cracking behavior of polyester fiberreinforced expansive clay," Applied Clay Science, vol. 142, pp. 163-172, 2017.

[20] I. Iasbik, D. C. De Lima, C. A. B. Carvalho, C. H. C. Silva, E. Minette, and P. S. A. Barbosa, "Geotechnical characterization of a clayey soil stabilized with polypropylene fiber using unconfined compression and resilient modulus testing data," in Resilient Modulus Testing for Pavement Components, pp. 114-125, ASTM Special Technical Publication (STP 1437), West Conshohocken, PA, USA, 2002.

[21] N. C. Consoli, M. D. T. Casagrande, P. D. M. Prietto, and A. N. Thomé, "Plate load test on fiber-reinforced soil," Journal of Geotechnical and Geoenvironmental Engineering, vol. 129, no. 10, pp. 951-955, 2003.

[22] L. David Suits, T. C. Sheahan, E. C. Ang, and J. E. Loehr, "Specimen size effects for fiber-reinforced silty clay in unconfined compression," Geotechnical Testing Journal, vol. 26, no. 2, article 10410, 2003.

[23] J. E. Loehr, R. J. Romero, and E.-C. Ang, "Development of a strain-based model to predict strength of geosynthetic fiberreinforced soil," in Proceedings of the Geosynthetics Research and Development in Progress, vol. 130-142, pp. 4037-4043, ASCE, Austin, TX, USA, January 2005.

[24] P. Sukontasukkul and P. Jamsawang, "Use of steel and polypropylene fibers to improve flexural performance of deep soil-cement column," Construction and Building Materials, vol. 29, pp. 201-205, 2012.

[25] P. Jamsawang, P. Voottipruex, and S. Horpibulsuk, "Flexural strength characteristics of compacted cement-polypropylene fiber sand," Journal of Materials in Civil Engineering, vol. 27, no. 9, article 04014243, 2015.

[26] P. Jamsawang, T. Suansomjeen, P. Sukontasukkul, P. Jongpradist, and D. T. Bergado, "Comparative flexural performance of compacted cement-fiber-sand," Geotextiles and Geomembranes, vol. 46, no. 4, pp. 414-425, 2018.

[27] T. Yetimoglu and O. Salbas, "A study on shear strength of sands reinforced with randomly distributed discrete fibers," Geotextiles and Geomembranes, vol. 21, no. 2, pp. 103-110, 2003.

[28] Y. Temel, I. Muge, and E. I. Orhan, "A study on bearing capacity of randomly distributed fiber-reinforced sand fills overlying soft clay," Geotextiles and Geomembranes, vol. 23, no. 2, pp. 174-183, 2005.

[29] A. R. Estabragh, P. Namdar, and A. A. Javadi, "Behavior of cement-stabilized clay reinforced with nylon fiber," Geosynthetics International, vol. 19, no. 1, pp. 85-92, 2012.

[30] M. D. T. Casagrande, M. R. Coop, and N. C. Consoli, "Behavior of a fiber-reinforced bentonite at large shear displacements," Journal of Geotechnical and Geoenvironmental Engineering, vol. 132, no. 11, pp. 1505-1508, 2006.

[31] C. Tang, B. Shi, W. Gao, F. Chen, and Y. Cai, "Strength and mechanical behavior of short polypropylene fiber reinforced and cement stabilized clayey soil," Geotextiles and Geomembranes, vol. 25, no. 3, pp. 194-202, 2007.

[32] A. P. S. Santos, N. C. Consoli, K. S. Heineck, and M. R. Coop, "High-pressure isotropic compression tests on fiberreinforced cemented sand," Journal of Geotechnical and Geoenvironmental Engineering ASCE, vol. 136, no. 6, pp. 885-890, 2010.
[33] S.-S. Park, "Unconfined compressive strength and ductility of fiber-reinforced cemented sand," Construction and Building Materials, vol. 25, no. 2, pp. 1134-1138, 2011.

[34] H. S. Chore and M. K. Vaidya, "Strength characterization of fiber reinforced cement-fly ash mixes," International Journal of Geosynthetics and Ground Engineering, vol. 1, no. 4, p. 30, 2015.

[35] A. A. S. Correia, P. J. Venda Oliveira, and D. G. Custódio, "Effect of polypropylene fibres on the compressive and tensile strength of a soft soil, artificially stabilised with binders," Geotextiles and Geomembranes, vol. 43, no. 2, pp. 97-106, 2015.

[36] M. Roustaei, A. Eslami, and M. Ghazavi, "Effects of freezethaw cycles on a fiber reinforced fine grained soil in relation to geotechnical parameters," Cold Regions Science and Technology, vol. 120, pp. 127-137, 2015.

[37] A. S. Zaimoglu, O. Tan, and R. K. Akbulut, "Optimization of consistency limits and plasticity index of fine-grained soils modified with polypropylene fibers and additive materials," KSCE Journal of Civil Engineering, vol. 20, no. 2, pp. 662-669, 2016.

[38] J. S. Kumar and P. Sharma, "Geotechnical properties of pond ash mixed with cement kiln dust and polypropylene fiber," Journal of Materials in Civil Engineering ASCE, vol. 30, no. 8, article 04018154, 2018.

[39] Public Work Research Institute of Japan (PWRI), Technology Using Soil High Grade Soil-Foam Mixed Stabilized Soil Method, Public Work Research Institute of Japan (PWRI), Tsukuba, Japan, 2005.

[40] C. J. Miller and S. Rifai, "Fiber reinforcement for waste containment soil liners," Journal of Environmental Engineering, vol. 130, no. 8, pp. 891-895, 2004.

[41] ASTM C1609, Standard Test Method for Flexural Performance of Fiber-Reinforced Concrete (Using Beam with Third-Point Loading), ASTM International, West Conshohocken, PA, USA, 2012.

[42] D. J. Kim, S. H. Park, G. S. Ryu, and K. T. Koh, "Comparative flexural behavior of hybrid ultra high performance fiber reinforced concrete with different macro fibers," Construction and Building Materials, vol. 25, no. 11, pp. 41444155, 2011.

[43] B. Nematollahi, J. Sanjayan, and F. U. A. Shaikh, "Comparative deflection hardening behavior of short fiber reinforced geopolymer composites," Construction and Building Materials, vol. 70, pp. 54-64, 2014.

[44] H. Khelifi, T. Lecompte, A. Perrot, and G. Ausias, "Mechanical enhancement of cement-stabilized soil by flax fibre reinforcement and extrusion processing," Materials and Structures, vol. 49, no. 4, pp. 1143-1156, 2016.

[45] N. C. Consoli, F. Zortéa, M. de Souza, and L. Festugato, "Studies on the dosage of fiber-reinforced cemented soils," Journal of Materials in Civil Engineering, vol. 23, no. 12, pp. 1624-1632, 2011.

[46] C. Rocco, G. V. Guinea, J. Planas, and M. Elices, "Mechanisms of rupture in splitting tests," ACI Materials Journal, vol. 96, no. 1, pp. 52-60, 1999.

[47] K. Sobhan and M. Mashnad, "Tensile strength and toughness of soil-cement-fly-ash composite reinforced with recycled high-density polyethylene strips," Journal of Materials in Civil Engineering, vol. 14, no. 2, pp. 177-184, 2002.

[48] M. Olgun, "Effects of polypropylene fiber inclusion on the strength and volume change characteristics of cement-fly ash stabilized clay soil," Geosynthetics International, vol. 20, no. 4, pp. 263-275, 2013. 


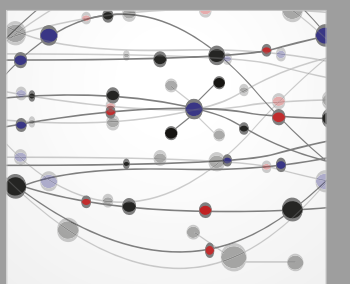

The Scientific World Journal
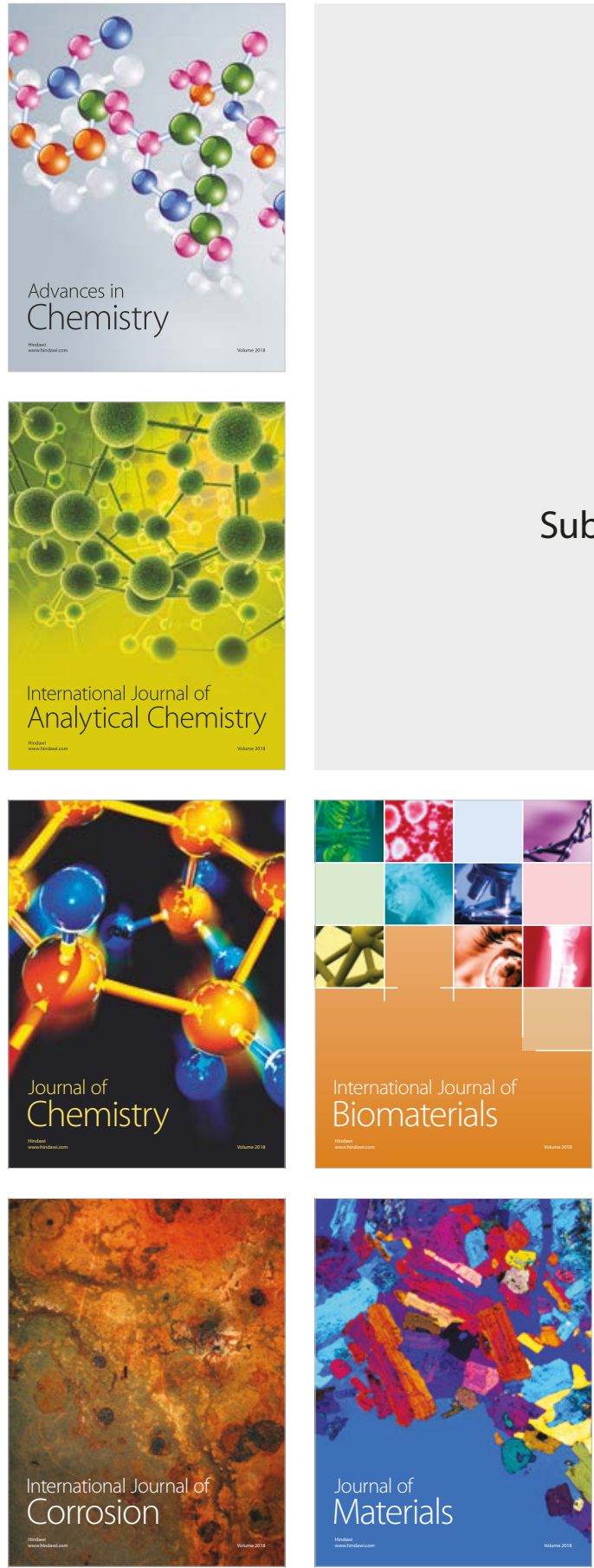

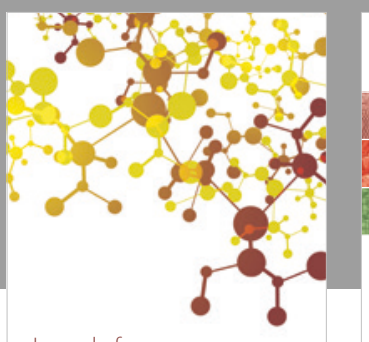

Journal of

Applied Chemistry
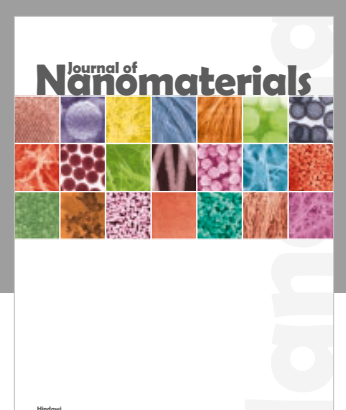

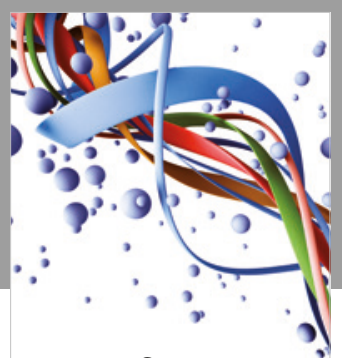

Scientifica

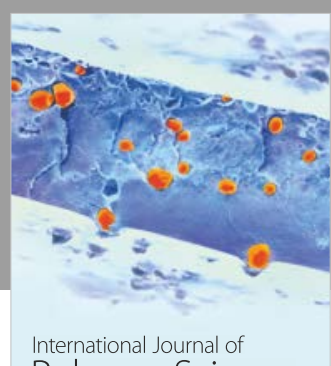

Polymer Science

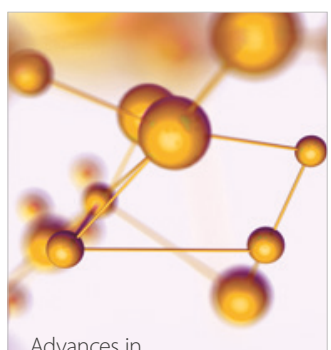

Physical Chemistry
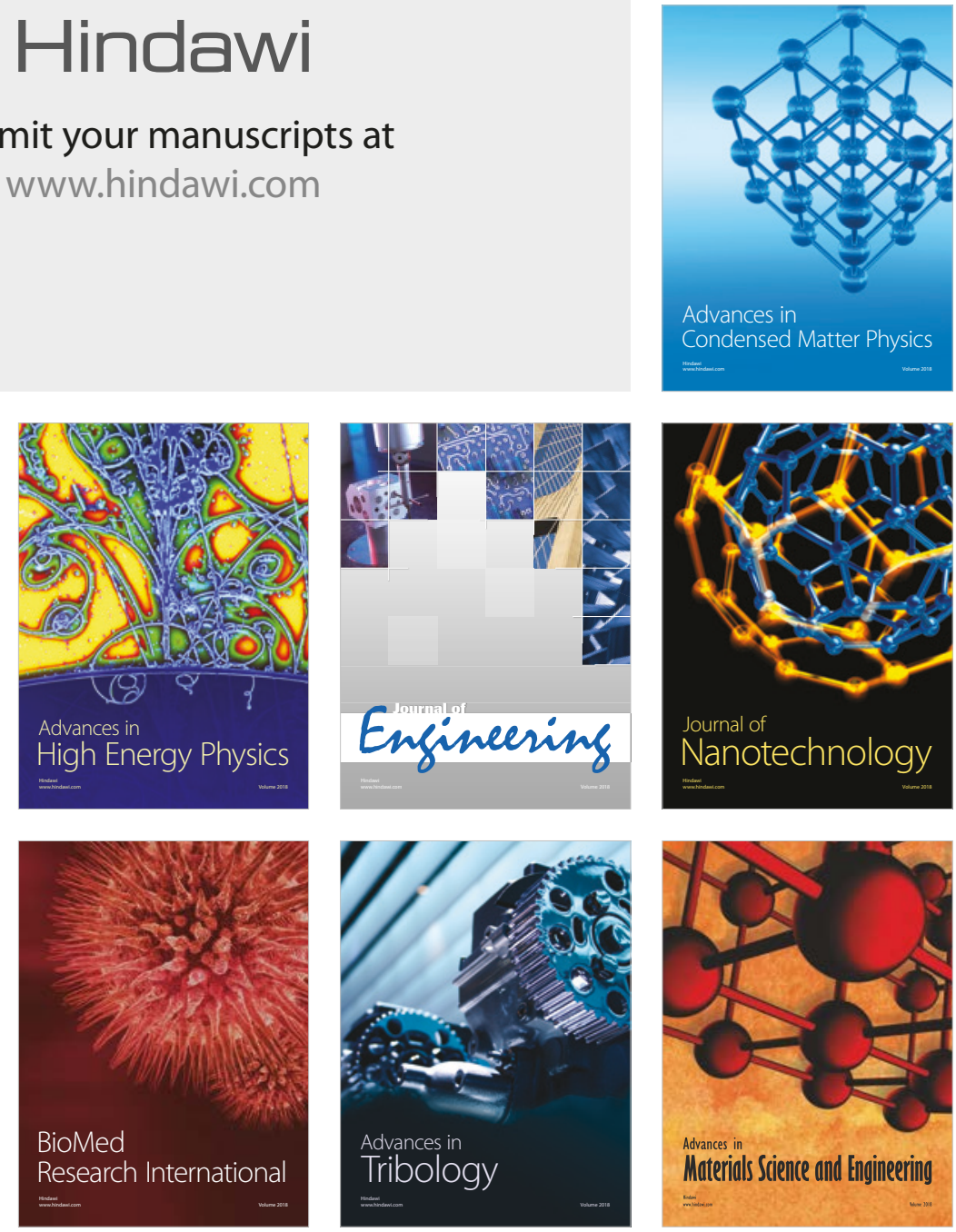